\title{
布の紫外線透過機構に関する研究
}

\author{
富山女子短期大学生活科学科 桑原 宣彰・尾畑 納子
}

\section{Mechanism of Transmission of Ultraviolet Rays through Fabrics}

\section{Nobuaki Kuwabara and Noriko Obata}

Department of Science of Living. Toyama Women's College 444 Mizukuchi, Gankaiji, Toyama, 930 01 Japan

\begin{abstract}
To examine the transmission of ultraviolet (UV) ray through various fabrics and to clarify its mechanism, the UV transmission and reflection spectra were measured for various kinds of fabrics and the results were compared with those for the films composed of the same polymers. The UV transmittance for films followed the Lambert-Beer law while that for fabrics followed the Kubelka theory, suggesting that the UV transmission through fabrics was influenced not only by absorption but also by scattering. Using the Kubelka theory, the absorption and scattering coefficients of fabrics could be determined separately. It was found that the UV trans mission of fabrics largely depended on the absorption of component fibers, although the contribution of scattering were not negligible. A modified Kubelka theory was proposed which was useful in facile determination of the scat. tering and absorption coefficients.
\end{abstract}

(Received May 27, 1993)

\section{1. 楮 吉}

日光による日烧けが，皮凬の光老化，さらには皮庯癌 の発生に深い関わりがあるという指摘がなされ，折から の地球環境問題が相俟って，身体につける化粧品や浅維 製品の紫外線カット性能[1]が注目されている。 布の紫外線カット性能の評洒は，最終的にはアメリカ で化粧品に対して行われているSPF 法（Sun Protection Factor）等〔2\}のように，身体で測定するより直接的な 方法が必要であろうが，一方，より簡便でより定量的な 評価法も必要と思われる。その一つとして分光光度計に よる方法(3)が考えられる。しかしながら布は, フィル ムのようなものと違って織維の部分と空気の部分とから なる峨維の集合体であり，その紫外線透過は䄉維自身に よる透過・吸収の他に，应散反射も加わって複雑である。 それゆえ，今までに定量的な検討が加えられていない。 本研究では，布を構成する栈維素材の透過能の比較を行 うとともに，䄉維自身による透過・吸収と拡散反射とを 分離して検討することを試みた。

\section{2. 実跧}

\section{1 試料}

実験に供した試布の詳細を，表1に示す。表中の試料 No. 1 - No. 9 は, 中尾フィルター工業侏製の染色用試 布であり，No.10は，クラレ(制製の紫外線カッ卜傤維の エスモを使用した布である。

またこの他に，比較のために，七ロハン $(20 \mu \mathrm{m}$ 厚)， 二軸延伸ポリエステル (O-PET:14 $\mu \mathrm{m}$ 厚)，二軸延伸 ナイロン (O-NY:18 $\mu \mathrm{m}$ 厚)，以上 3 種のフィルムも使 用した。それらはいずれも常法によって前処理して用い た。

\section{2 紫外線透渦率の测定}

透過率㧍上び反射率の測定には，日本分光工業㑣製の 分光光度計 UVIDEC-610C に，同社製の皘分球装置 TIS-341型を取り付けたものを使用した。積分球装置の 概略図を図1に示した。MgOをコーティングした内径 $60 \mathrm{~mm}$ の積分球は，試料により拡散反射または拡散透 過された光を、ほとんど全部積分球内に取り込んで底部 にある㭘知器で測定できるようになっている。また同装 置はダブルビームで，試料側，参照側とも積分球内への 光の入射口とその对角線上に反射板ホル多がある。そし 
Table 1 Characteristics of Fabrics

\begin{tabular}{|c|c|c|c|c|c|c|}
\hline \multirow{2}{*}{ No. } & \multirow{2}{*}{ Material } & \multirow{2}{*}{ Weave } & \multicolumn{2}{|c|}{ Count } & \multirow{2}{*}{$\begin{array}{c}\text { Thickness }^{\text {a) }} \\
(\mathrm{mm})\end{array}$} & \multirow{2}{*}{$\begin{array}{l}\text { Fiber } \\
\text { content } \\
\text { ratio }{ }^{\circ)}\end{array}$} \\
\hline & & & Warp & Weft & & \\
\hline 1 & Rayon & Plain & $120 \mathrm{D}$ & $120 \mathrm{D}$ & 0.195 & 0.297 \\
\hline 2 & Polyester & Plain & $50 \mathrm{D}$ & $50 \mathrm{D}$ & 0.100 & 0.520 \\
\hline 3 & Nylon & Plain & $50 \mathrm{D}$ & $50 \mathrm{D}$ & 0.121 & 0.450 \\
\hline 4 & Silk & Plain & $21 \mathrm{D}$ & $210 / / 2$ & 0.090 & 0.217 \\
\hline 5 & Acetate & Plain & $120 \mathrm{D}$ & $120 \mathrm{D}$ & 0.110 & 0.427 \\
\hline 6 & Wool & Plain & $1 / 52$ & $1 / 52$ & 0.249 & 0.332 \\
\hline 7 & Cotton & Plain & $40 \mathrm{~S}$ & $40 \mathrm{~S}$ & 0.267 & 0.282 \\
\hline 8 & Acryl & Plain & $1 / 64$ & $1 / 64$ & 0.252 & 0.333 \\
\hline 9 & $\mathrm{C} / \mathrm{P}^{\mathrm{c}}$ & Plain & $40 \mathrm{~S}$ & $40 \mathrm{~S}$ & 0.250 & 0.306 \\
\hline 10 & Polyester & Plain & $40 S$ & $40 S$ & 0.250 & 0.369 \\
\hline
\end{tabular}

a) Measured under $28.5 \mathrm{gf} / \mathrm{cm}^{2}$

b) Fiber volume per unit volume of fabrics.

c) Blending fabrics (Cotton/Polyester $=65 / 35$ )

d) Fabrics, ESMO (Kuraray Co.,Ltd)which shields ultraviolet ray in sun light.

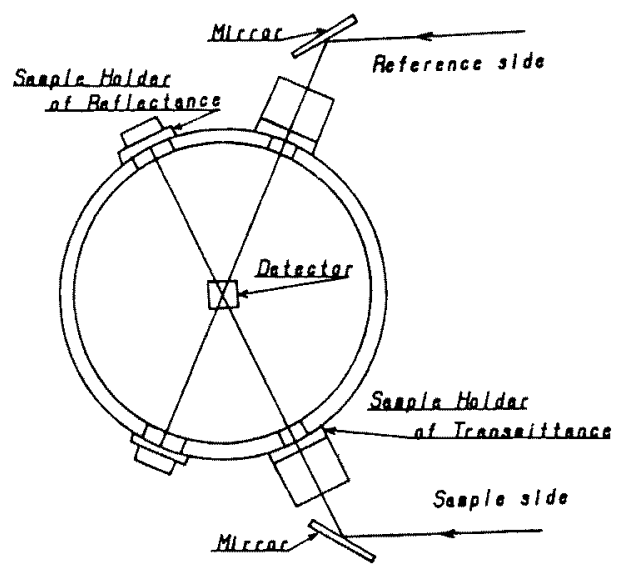

Fig. 1 Schematic diagram of integrating sphere on spectrophotometer for ultraviolet light.

て透過率は，その両方の反射板ホルダに標準白板を取り 付け，試料側の入射口に試料を置いて測定する。また反 射率は，試料側の反射ホルダに標準白板にかえて試料を 置いて測定を行う。以上のような構造をむったものであ 万。

使用可能波長は220－800 nmであるが、今回は230〜 $400 \mathrm{~nm}$ の範囲で行った。そして被長範囲を400～320 $\mathrm{nm}(\mathrm{UV}-\mathrm{A}), \quad 320-290 \mathrm{~nm} \quad(\mathrm{UV}-\mathrm{B}), \quad 290 \sim 230 \mathrm{~nm}$

(UV-C) の3つに分け，その籍围における平均の透過 率および反射率を積分强度から求めた。今回はその中で

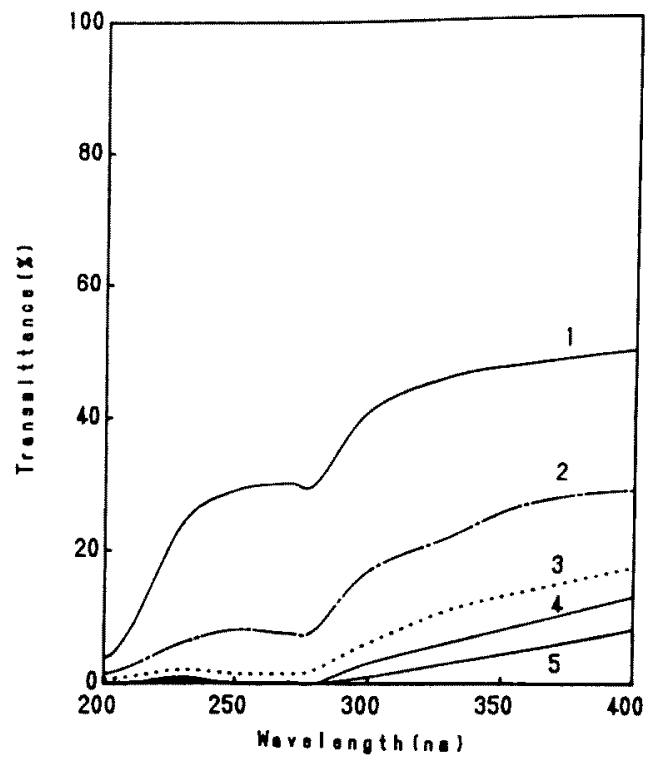

Fig. 2 UV transmission spectra for rayon fabric sheets. 1,2, 3, 4 and 5 denote the number of piled-up sheets.

特に，太陽光中で大部分を占めるUV-A を中心に使用 して検討した。

\section{3. 拮果及び考宗}

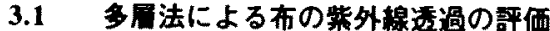

高い精度の透過係数を得るためには，厚みの異なる試 料について透過光を測定することが望ましい。そこで， 試料布を何枚か重わ，それによって試料厚みを変化させ るという方法を用いて検討した。その一例として，レー ヨン布を 1 枚〜 5 枚重ねて测定した時の紫外線吸収スぺ クトルの变化を図 2 に示した。当然のことであるが，枚 数が多く厚みが增すに従って透過率は堿少する。

このょうにして湘定したスべクトルから，UV-A， UV-B，UV-C，各領域における透過率を透過光の積分 強度によって求める。その場合，布の重ね方によって值 が異なること，すなわち再現性の有無が棌念されるので， 先ずそれを確認した。試布としてレーヨン，ポリエステ ル，およびナイロンの3 種を用い、サンプル 2 枚を、1 つの方法としてお互い夕テ糸と夕テ采、ヨコ系とヨコ系 が同じ方向になるように重ねたもの，次に片方を45度回 転させたもの，さらにお互いの夕テとヨコが重なるよう に，即ち初かの方法の位置から90度回転させたものの 3 つの場合について，測定し比較した。その際の透過率の 平均値と標染偏差とを表 $2 に$ 示した。表からわかるよう に，それらの間に有意な差は認められず，試料の重ね方 
Table 2 Average Value( $\mathrm{x}$ ) and Standard Deviation( $\sigma$ ) of UV Transmittance (\%) at Various Angles between Weave Directions of Two-layered Fabrics

\begin{tabular}{|c|c|c|c|c|c|c|c|}
\hline \multirow{2}{*}{ Sample } & \multirow{2}{*}{ UV } & \multicolumn{2}{|c|}{$0^{\circ}$} & \multicolumn{2}{|c|}{$90^{\circ}$} & \multicolumn{2}{|c|}{$45^{\circ}$} \\
\hline & & $\mathrm{x}$ & $\sigma$ & $x$ & $\sigma$ & $\mathbf{x}$ & $a$ \\
\hline \multirow[t]{3}{*}{ Rayon } & A & 25.3 & 1.41 & 25.3 & 0.65 & 25.6 & 0.77 \\
\hline & B & 17.6 & 0.83 & 17.4 & 0.32 & 17.5 & 0.78 \\
\hline & $c$ & 6.44 & 0.63 & 6.43 & 0.17 & 6.50 & 0.22 \\
\hline \multirow[t]{3}{*}{ Polyester } & A & 15.5 & 0.54 & 15.2 & 0.30 & 15.3 & 0.38 \\
\hline & B & 0.67 & 0.014 & 0.63 & 0.056 & 0.58 & 0.043 \\
\hline & C & 0.47 & 0.080 & 0.45 & 0.009 & 0.48 & 0.042 \\
\hline \multirow[t]{3}{*}{ Nylon } & A & 22.2 & 0.46 & 22.6 & 0.24 & 22.4 & 0.21 \\
\hline & B & 9.14 & 0.11 & 9.04 & 0.22 & 9.16 & 0.22 \\
\hline & C & 3.68 & 0.058 & 3.73 & 0.069 & 3.71 & 0.13 \\
\hline
\end{tabular}

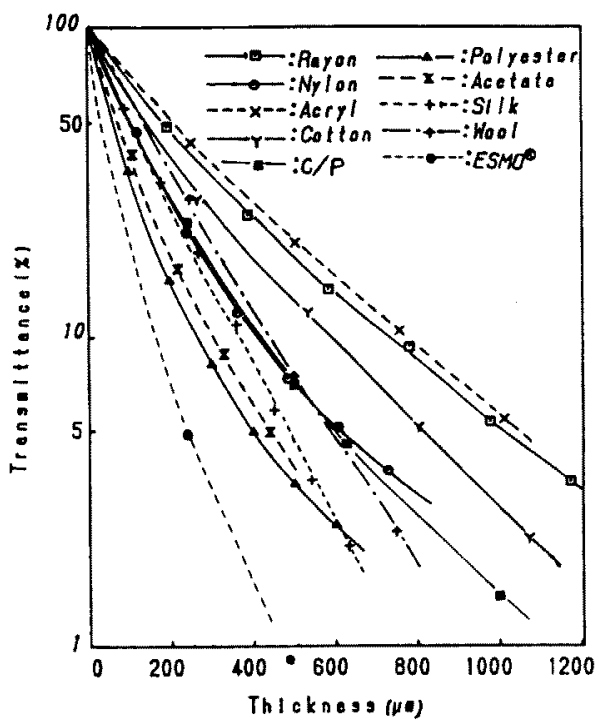

Fig. 3 Transmittance in the UV.A region as a func. tion of thickness for various fabrics.

の違いによる測定値の誤差は無視し得ることが確かめら れた。

各種サンプルについての UV.A 透過率の対数值と厚 さとの関係をとり図 3に示した。それらは直線にならず， Lambert-Beerの法則が成り立たない。この点は後に述 べるが、穖維自身による透過・吸収以外に搪散による効 果が加わるためと考えられる。

また，布は䋞維100\%で構成されておらず，中に空気 の部分が含まれる。そのために同じ樴維から成る布でも， その峨維部分の比率, 即ち織維含有率 $\mathrm{f}$ が異なると透過 率は変化すると考えられる。図 3 に示すとおり透過率の
Table 3 Apparent absorption Coefficient ( $\alpha$ ) for Va. rious Fibers and Films

\begin{tabular}{lclc}
\hline \multicolumn{1}{c}{ Fabrics } & $\alpha\left(\mathrm{cm}^{-1}\right)^{\text {a) }}$ & \multicolumn{1}{c}{ Films } & $\alpha\left(\mathrm{cm}^{-1}\right)$ \\
\hline Rayon & 32.0 & Cellophane & 47.2 \\
Nylon & 48.8 & Nylon & 60.8 \\
Polyester & 56.4 & Polyester & 114.0 \\
\hline \multirow{2}{*}{ at $300 \mu \mathrm{m}$} & & &
\end{tabular}

对数值と厚みの関係は直線でないが，狭い範囲では直楾 で近似でき，Lambert-Beerの式 1 が成り立つと仮定で きる。

$$
I_{1}=I_{0} e^{-a l}
$$

ここで示される $I_{0}$ は入射光の光束であり， $I_{1}$ は透過光の 光束，1は試料厚またaは空気と轹維の混合体である 布の平均吸光係数である。そ机は空気と織維の吸光保数 をそれぞれ 0， $\alpha$ とすると狭い範囲で， $\mathrm{a}=\alpha \times \mathrm{f}$ とな る。

そこで，この関係を使って試布レーヨン，ポリエステ ル，および+イロンのみかけの吸光係数 $\alpha$ を求め表 3 に 示す。この場合の値は图 3 の厚さ300 $\mu \mathrm{m}$ における勾配 より算出した。

今，図 3 から比較的轿維含有率が近いもので，布を满

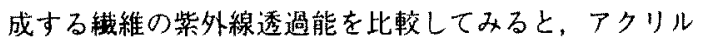
とセルロース系の織維である綿，レーヨンは透過率が高 く紫外線の遮断効果が小さいということができる。ここ では詳細な結果は省略したが，图2に示したレーヨン布 のスペクトルからもわかるとおり，UV-A，UV-B， UV-C では，波長の長いUV-A の透過が大きく，UV-B， UV-Cでは小さいという一般に予想される傾向を示した。 特に主鎖にベンゼン環をもつために透過が小さいといわ れるポリエステルでは，殆ど0に近い值となる。また， ポリエステルに紫外線遮断性能を付与したものでは，通 常のポリエステル布よりも䄉維含有率が低いにもかかか らずその透過は更に小さく改鲜の效果が現れている。䄸 とポリエステルを35/65の比率で混紡したサンブルでは、 綿とポリエステルの間の值をとるが，その值は，それを 楆成する䄉維，すなわち線とポリエステルそれぞれの透 過率とそれらの混合容積比を用いて，単純に比例計算し て得られる值よりも，かなり小さい值となった。すなわ ち混合容積比に対して加成性は成り立たず，吸取の大き いちの織維であるポリエステルの影製を強く受ける。

\section{2 フィルムによる検討}

布に比べて比較的均一で，等気の含有率が無視できる と思われるフィルム状のサンプル，七ロハン，ポリエス 


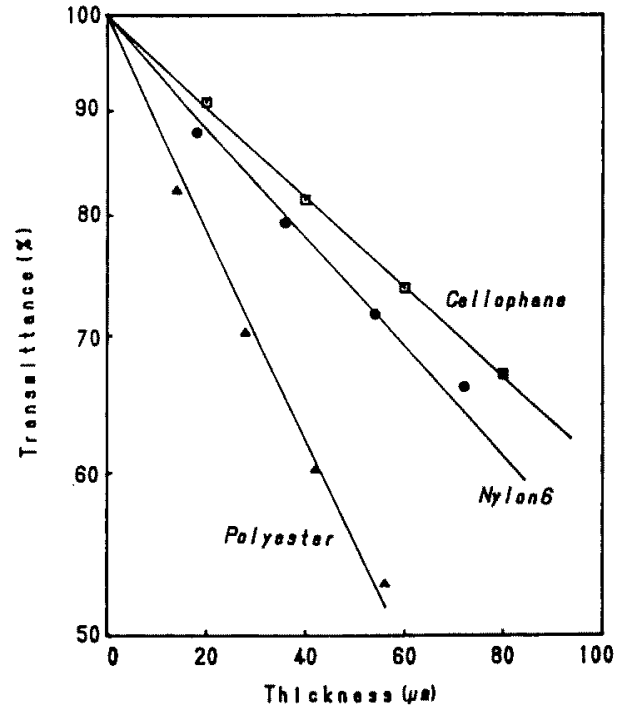

Fig. 4 Transmittance in the UV-A region as a func. tion of thickness for various films.

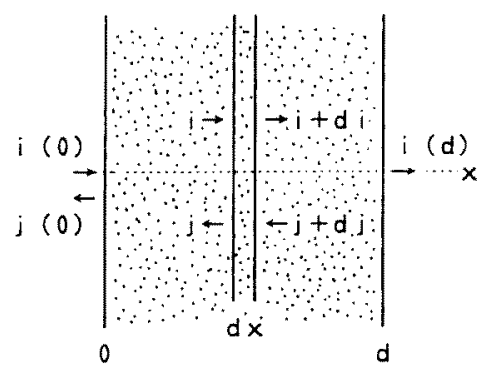

Fig. 5 Schematic representation of UV transmission for fabrics (Kubelka mode according to Hayakawa[4])

テルナイロンを用いて同様の実験を行った。すなわち、 布の場合と同样にフィルムのサンプルを何枚か重わるこ とによって厚みを变え，透過率を測定した。比較的吸収 の小さいUV-Aの結果を，図 4 に示した。布と違って 透過率の对数值が，厚みの增加に逆比例して直線となっ た。るこでこの関係を用いて透過係数 $\alpha$ を求めた。そ の結果は表 3 に示すとおりである。前述のとおり，布の 紫外線透過に対しては，荗維自身に上る吸収と空腙部の 影響とがあるが，フィルムと布それぞれの構成物質の種 類で比べると，いずれもセルロース>ナイロン>ポリエ ステルの順に大きくこのことは䋞維自身による吸収の 影翌が大きいことを示唆している。

\subsection{Kubelkaの理諭による解析}

布の透過は轼維自身の吸収によって大きな影響を受け るがそれのみでは決まらず，拡散反射の影晦についても 考える必要がある。すなわち，吸収の影脾と搪散反射の
影響とを定量化して考える必要がある。吸収と拡散反射 の雨方を考度して透過機構を解析した例として, Kubel ka の理論[4]がある。それい主に粉体を対象としたもの であるが，布に対しても染色 [5]や洗浄 (6)の分野で応用 されており，そこでこのKubelkaの理論を道用して以 下の検討を行った。

Kubelkaの理論の概要は早川 (4]によると以下のよう


おいて，その厚さ方向に $\mathrm{x}$ をとる。そして微小層 $\mathrm{dx}$ 考え， $\mathrm{x}$ から正方向の光束を $\mathrm{i} と し ，$ 層 $\mathrm{dx}$ の中でのそ の変化を di とする。また散乱によって生じる負方向の 光束を $\mathrm{j} と し ，$ 層 $\mathrm{dx}$ の中でのその変化を djとする。光 の吸収及び散乱が厚さ $\mathrm{dx}$ に比例するとすると，それぞ れから次の式 $2 ， 3$ が成り立つ。

$$
\begin{aligned}
& -\mathrm{di}=(\alpha+\mathrm{S}) \mathrm{idx}-\mathrm{Sjdx} \\
& -\mathrm{dj}=(\alpha+\mathrm{S}) \mathrm{j}(-\mathrm{dx})-\mathrm{Si}(-\mathrm{dx})
\end{aligned}
$$

ここで， $\alpha$ は吸光係数，Sは散乱係数である。

これらより，i，jに関して導かれる微分方程式は次の 式 4，5になる。

$$
\begin{aligned}
& \frac{d^{2} i}{d x^{2}}=S^{2} b^{2} i \\
& j=\frac{1}{S d x}+(1+q) i
\end{aligned}
$$

ここで，q及び $\mathrm{b}$ は次で示される做である。

$$
q=\frac{\alpha}{S} \quad b^{2}=(1+q)^{2}-1
$$

式 4 の一般解は次の式 6 で示され

$$
\mathrm{i}=\mathrm{C}_{1} \mathrm{e}^{\mathrm{Sbx}}+\mathrm{C}_{2} \mathrm{e}^{-\mathrm{Sbx}}
$$

$\left(\mathrm{C}_{1}, \mathrm{C}_{2}\right.$ は積分定数 $)$

$\mathrm{x}=0$ のとき，i=i(0)とすると，(6)は次の式 7 になる。

$$
\left.\mathrm{i}=\mathrm{C}_{1} \mathrm{e}^{\mathrm{Sbx}}+\mid \mathrm{i}(0)-\mathrm{C}_{1}\right\} \mathrm{e}^{-\mathrm{Sbx}}
$$

また（5)に(7)を代入して，式 8 が得られる。

$$
\begin{aligned}
j= & C_{1} b e^{S b x}-\left\{i(0)-C_{1}\right\} b e^{-S b x} \\
& +(1+q)\left(C_{1} e^{S b x}+\left|i(0)-C_{1}\right| e^{-S b x}\right]
\end{aligned}
$$

図 5 に示すようにi(0)の光束が入って，i(d)が透過 L， $\mathrm{j}(0)$ が反射すると，透過率 $\mathrm{T}(\mathrm{d})$ と反射率 $\mathrm{R}(\mathrm{d})$ は， それぞれ T $(\mathrm{d})=\mathrm{i}(\mathrm{d}) / \mathrm{i}(0) ， \mathrm{R}(\mathrm{d})=\mathrm{j}(0) / \mathrm{i}(0)$ であり， それらは式 7，8に試料の厚さを $\mathrm{d}, \mathrm{j}(\mathrm{d})=0$ の境界条 件を入れて求めると, 次の 9,100 形になる。

$$
\begin{aligned}
& \mathrm{T}(\mathrm{d})=\mathrm{b} /\left\{\mathrm{b} \cosh \left(\gamma_{\mathrm{d}}\right)+(1+\mathrm{q}-\mathrm{b}) \sinh \left(\gamma_{\mathrm{d}}\right)\right\} \\
& \mathrm{R}(\mathrm{d})=\left\{(1+\mathrm{q})-\mathrm{b} \cosh \left(\gamma_{\mathrm{d}}\right)\right\} \\
& +\left\{\mathrm{b} / \sinh \left(\gamma_{\mathrm{d}}\right) \mid \mathrm{T}(\mathrm{d})\right.
\end{aligned}
$$






Fig. 6 Reflectance in the UV-A region as a function of thickness for various fabrics.

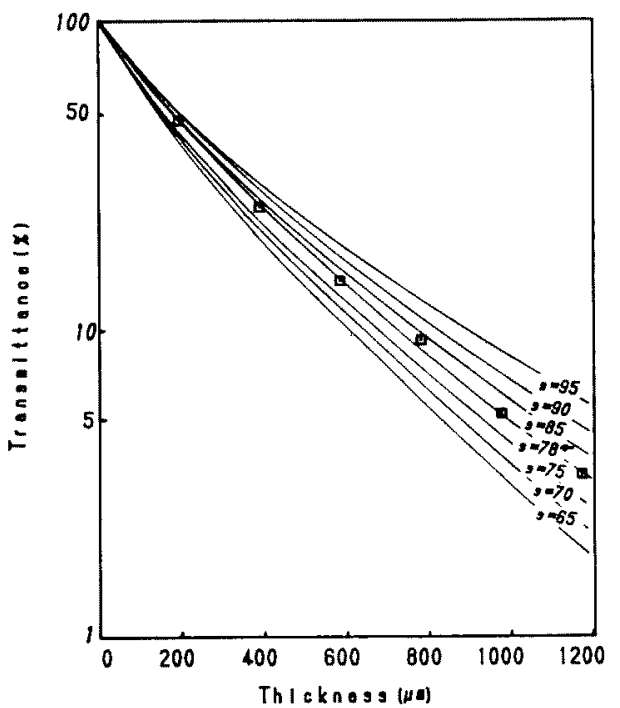

Fig. 7 Curve fitting for rayon fabrics with various values of $S: \square$. Experimental data; lines; Calculated with Eq. 9.

ここで， $\gamma=\mathrm{Sb}$ である。

今, 厚さが著しく大きい時, 即ち $\mathrm{d} \rightarrow \infty$ の時, 透過率 $T_{\infty}$ と，反射率 $R_{\infty}$ はそれぞれ $T_{\infty}=0 ， R_{\infty}=(1+q)-$ b となり，後者の関倸から次の式11すなわち Kubelka 関 数が得られる。

$$
\frac{\alpha}{\mathrm{S}}=\frac{\left(1-\mathrm{R}_{\infty}\right)^{2}}{2 \mathrm{R}_{\infty}}
$$

したがって，厚さを著しく大きくした時の反射率 $R_{\infty}$

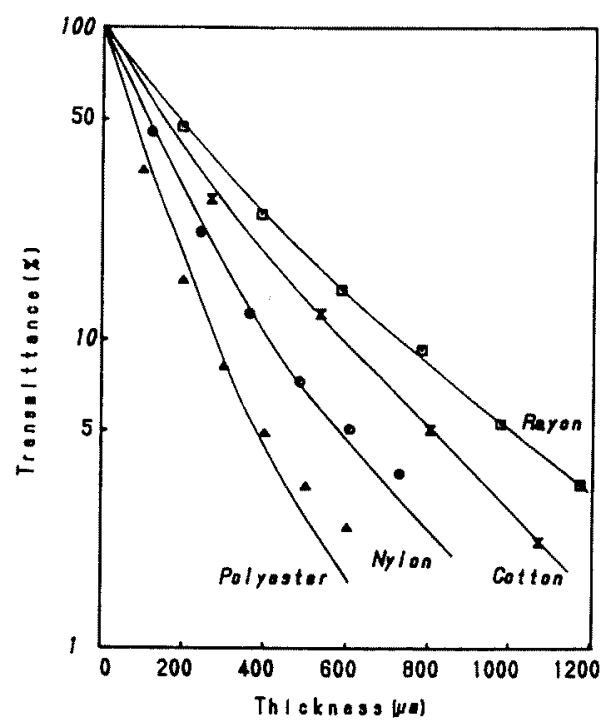

Fig. 8 Transmittance in the UV-A region as a funetion of thickness for various fabrics: Curves were calculated with Eq. 9.

を求めると式11から，散乱係数 $\mathrm{S}$ と吸光係数 $\alpha$ の比が

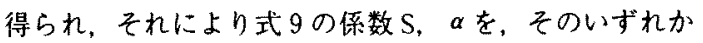
1つにすることができる。そしてその式を用いてカーブ フィッティング法により，実験值との差が最も小さくな る時の倸数 S（または $\alpha$ ）を求めることにより, 散乱保 数 $\mathrm{S}$ と更に吸光保数 $\alpha$ が得られる。

この方法を用いて、ここではUV-Aの領域值を解析 した。まず，R⿻を求めるため，布を何枚も重ねて厚さ を変え，反射率を測定した。その結果を図6に示す。ど の試料も厚みを增していくと反射率は高くなるが，さら に增してもそれ以上は大きくならない一定の值に近つく。 その值を $\mathrm{R}_{\infty}$ として，式11から $\alpha / \mathrm{S}=\mathrm{q}$ を求めた。そ してその值を式 9 に入れて，係数をSのみにした後， 実験値と式 9 から得られる曲線との差が最も小さくなる 時の值を求め，散乱係数 $\mathrm{S}$ とした。図 7 に，その一例 であるレーヨンにおける結果を示した。 $S=78 \mathrm{~cm}^{-1}$ の時, 理論曲線と実験值との差が最も小さくなる。これが求め る散乱係数 Sの值である。図には種々の違った $\mathrm{S} の$ 值 を入れて得られる曲線を併せて示したが，Sが78 $\mathrm{cm}^{-1}$ から離机るに従って，実駼值からのズレが大きくな る。また, 図8にはレーヨンの他に䄸、ナイロン、ポリ エステルについての結果を同様に示した。いずれも実験 值と曲線とがよく一致しておりこの取扱いの妥当性を 証明している。

以上のようにして求めた $\mathrm{R}_{\infty} ， \alpha / \mathrm{S} ， \alpha$ 及び $\mathrm{S} の$ 結 果を表 4 にまとめて示した。吸光係数は，試料の中で最 
Table 4 Maximum of Reflectance( $R_{\infty}$ ), Ratio of Absorption Coefficient( $\alpha$ ) to Scattering Coefficient(s), $s$ and $\alpha$ for Various Fabrics

\begin{tabular}{|c|c|c|c|c|c|c|c|c|}
\hline \multirow{2}{*}{ Sample } & \multicolumn{3}{|c|}{$R_{\infty}(\%)$} & \multicolumn{3}{|c|}{$\alpha / \mathrm{s}$} & \multirow{2}{*}{$\begin{array}{c}\left.\mathrm{s}^{-1}\right) \\
\left(\mathrm{cm}^{-1}\right) \\
\mathrm{UV}-\mathrm{A}\end{array}$} & \multirow{2}{*}{$\begin{array}{c}\alpha \\
\left(\mathrm{cm}^{-1}\right) \\
U V-A \\
\end{array}$} \\
\hline & UV-A & UV-B & UV-C & UV-A & UV-B & $\mathrm{UV}-\mathrm{C}$ & & \\
\hline 1 Rayon & 73.5 & 57.0 & 32.9 & 0.048 & 0.162 & 0.684 & 78 & 3.7 \\
\hline 2 Polyester & 40.5 & 9.7 & 8.4 & 0.437 & 4.20 & 5.02 & 96 & 40.6 \\
\hline 3 Nylon & 45.0 & 20.0 & 12.5 & 0.336 & 1.26 & 3.06 & 70 & 23.5 \\
\hline 4 Silk & 52.0 & 31.5 & 8.3 & 0.243 & 0.745 & 5.07 & 90 & 21.9 \\
\hline 5 Acetate & 53.0 & 32.0 & 19.0 & 0.208 & 0.723 & 1.73 & 114 & 23.7 \\
\hline 6 Wool & 30.5 & 7.3 & 3.7 & 0.792 & 5.93 & 12.5 & 39 & 30.9 \\
\hline 7 Cotton & 70.0 & 57.0 & 34.0 & 0.064 & 0.162 & 0.641 & 89 & 5.7 \\
\hline 8 Aclyl & 54.0 & 32.0 & 15.7 & 0.196 & 0.723 & 2.26 & 47 & 9.2 \\
\hline $9 \mathrm{c} / \mathrm{P}$ & 48.3 & 14.4 & 12.5 & 0.277 & 3.09 & 3.06 & 76 & 21.1 \\
\hline 10 Polyester & 34.0 & 5.3 & 5.2 & 0.830 & 8.46 & 8.64 & 98 & 81.3 \\
\hline
\end{tabular}

も高いものと低いものとでは20倍以上の差があり、この ことは前述したように布の透過度の大小に対して，䄉維 自身による透過・吸取の影響が大きいことを示している。 一方，散乱係数は，試料間の差が 3 倍程度と吸光係数に 比べて小さく，布の紫外楾透過に対して全体的には影響 があるが，試料間の差に対しては影製が少ないことを示 している。以上の点から，布の紫外線の遮断性は，散乱 の効果よりも，むしろ练䧽自身による吸収の效果の影響 が高いことが確諗された。ここで注意しなければならな い点は，図中の吸光係数は，䄉維自身の值ではなく布と しての値である点である。それらは織維含有率が増せば それに比例して大きくなると考えられる。そこで，今吸 光係数が阵維含有率に単純比例すると仮定して、比例計 算によって瀻維含有率 $100 \%$ におるUV-A の吸光係数 を求めると, レーヨン $15.8 \mathrm{~cm}^{-1}$, ナイロン $52.2 \mathrm{~cm}^{-1}$, ポリエステル78.1 $\mathrm{cm}^{-1}$ となった。一方フィルムでは図 4 から, 七ロハン $47.2 \mathrm{~cm}^{-1}$, ナイロン $60.8 \mathrm{~cm}^{-1}$, ポリ エステル114 $\mathrm{cm}^{-1}$ が得られた。それらの值は必ずしも完 全には一致していないが，雨者の形状の違い，また履歴 が異なることによる結晶搆造等の違いを考えると，それ らは近い值であると言ってよく、この結果からも Kubelka の理論を適用した本方法の妥当性が証明される。

\section{4 変形 Kubelka 理譮での解析}

前項では，Kubelkaの理詥に良って解析を行い吸光係 数と散乱係数を得たが，その方法は煩雑で，特に係数 S および $\alpha$ を求めるのが難しい。そこで，より簡略化した 方法を考案した。以下でその方法の妥当性を確かめた。

今，布のように比較的厚みの小さいものでは，表面で の反射率 R(d)はjにほほ比例しiに反比例すると考之 ると, 次の式 12 とな。

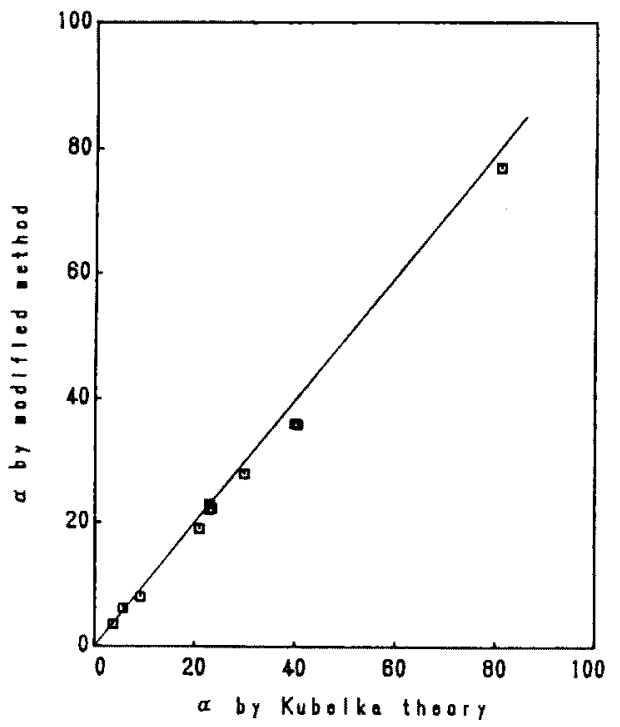

Fig. 9 Comparison of $\alpha$ values obtained by original and modified Kubelka theories.

$$
j=i R(d)
$$

この式 12 と式 2 より， $\mathrm{T}(\mathrm{d})=\mathrm{i}(\mathrm{d}) / \mathrm{i}(0)$ を求めて次の式 13 得られる。

$$
\ln T(d)=-|q+1-R(d)| S d
$$

従って，式13に一定厚dにおける透過率 $\mathrm{T}(\mathrm{d})$ と反射率 $\mathrm{R}(\mathrm{d})$ ，また式11から得られるqを入れることにより， $\mathrm{S}$ 及び $\alpha$ が求まる。

そこで，一定厚み $\mathrm{d}=300 \mu \mathrm{m}$ における值を用いて， 以下の計算を行った。即ち，図 3 , 図 6 から, 厚みd= $300 \mu \mathrm{m}$ における透過率 $\mathrm{T}(300)$ と反射率 $\mathrm{R}(300)$ を求め, 
それらと表 4 に示す $\alpha / \mathrm{S}(=\mathrm{q})$ の值とを用いて，散乱 俰数 S, 更に吸光保数 $\alpha$ を求めた。得られた $\alpha$ 値と, 先 にKubelkaの方法で求めた值との関係を図 9 に示した。 再者はよく一致しており，簡略化したこの方法が信頼で きるものであることが確かめられた。

\section{4. 桔 語}

布の紫外線透過は，それが橦維と空隙とからなる不均 一な構造であるため, 䄉維自身による透過・吸収以外に 拡散反射が加わって複雑な举動を示す。したがって，そ の機構の解明の第一は，䄉維自身による吸取と搪散反射 との関係を明らかにすること，すなわち吸光係数と散乱 係数を求めることである。

そこで本研究では，何枚かの試料を重ねることによっ て厚みを変化させて透過率および反射率を測定し，その 值を基に，主に粉体に適応される Kubelkaの理論を用 いて吸光保数及び散乱係数を求めた。ささらに，Kubelka の方法を変形し，より簡略化した方法を考案し，それに よって吸光係数と散乱係数を求めたところ，両者の值は よく一致し，その方法の妥当性か確認された。それらの
結果によると，紫外線透過性の布間の差には，散乱係数 よりも吸光係数の影響が強いことがわかった。

今回得られた知見は，吸光，散乱それぞれに与える種 々の因子の解明に有用であり，今後布に特有な散乱の影

幚について詳しく検討を行う予定である。 付記 本研究の一部は, 日本瀻維製品消費科学会研究発 表会（1992年6月13日，名古屋）で発表した。

\section{文献}

1. 山崎義一, 織消誌, 33，129 (1992).

2. 本好捷宏, フレグランスジャーナル，55 (1991-9)。

3. 上田充夫, 吉村由利香, 金谷 薰, 染色工業, 40, 59 (1992).

4. 早川宗八郎, 「粉体一理論と応用一」(久保輝一郎 編), 丸善, p.389 (1979) ; P. Kubelka, J. Opt. Soc. Am., 38, 448 (1948).

5. 松井健一,「色彩科学ハンドブック」(色彩科学協会 稨), 南江堂, p.448 (1962).

6. 矢部彦章, 林雅子, 「被服整理学概論」, 光生館, p.37 (1967). 